\title{
The Prognostic Implications of Bone Invasion in Gingival Squamous Cell Carcinoma
}

\author{
SHOKO YOSHIDA ${ }^{1}$, TSUYOSHI SHIMO ${ }^{1}$, YURIKA MURASE ${ }^{1}$, KIYOFUMI TAKABATAKE $^{2}$, KOJI KISHIMOTO ${ }^{1}$, \\ SOICHIRO IBARAGI ${ }^{1}$, NORIE YOSHIOKA ${ }^{1}$, TATSUO OKUI ${ }^{1}$, HITOSHI NAGATSUKA $^{2}$ and AKIRA SASAKI ${ }^{1}$ \\ ${ }^{1}$ Department of Oral and Maxillofacial Surgery, \\ Okayama University Graduate School of Medicine, Dentistry and Pharmaceutical Sciences, Okayama, Japan; \\ ${ }^{2}$ Department of Oral Pathology and Medicine, Okayama University Graduate School of Medicine, \\ Dentistry and Pharmaceutical Sciences, Okayama, Japan
}

\begin{abstract}
Background/Aim: This study evaluated the associations between bone invasion of gingival squamous cell carcinoma (SCC) and clinicopathological manifestations, and aimed to determine whether bone invasion is an independent prognostic factor in gingival SCC. Patients and Methods: The study was a retrospective review of 78 patients with gingival SCC who underwent surgery with curative intent. The level of bone invasion was pathologically categorized as medullary, cortical or no bone invasion. Results: Cortical and medullary bone invasion was present in 29 and 22 patients, respectively. There was a significant association between medullary bone invasion and tumor size $(p=0.017)$, pathological $N$ classification $(p<0.001)$, differentiation $(p=0.017)$ and lymphovascular invasion ( $p=0.007)$. Medullary bone invasion and lymphovascular invasion were independent predictors of reduced overall survival ( $p=0.015$, 0.048); medullary bone invasion was also an independent predictor of reduced disease-specific survival $(p=0.018)$. Conclusion: Pathologically-proven medullary bone invasion and lymphovascular invasion were found to be key prognostic factors in gingival SCC. The results suggest that it is necessary to consider adjuvant therapy in patients with medullary bone invasion.
\end{abstract}

Gingival squamous cell carcinoma (SCC) arises from the mucosal surface of the oral gingiva, and frequently invades the maxillary or mandibular bone (1-3). The prognostic implications of mandible bone invasion in oral SCC are

Correspondence to: Tsuyoshi Shimo, Department of Oral and Maxillofacial Surgery, Okayama University Graduate School of Medicine, Dentistry and Pharmaceutical Sciences, 2-5-1 Shikatacho, Kita-ku, Okayama 700-8525, Japan. Tel: +81 862356702, Fax: +81862356704, e-mail: shimotsu@md.okayama-u.ac.jp

Key Words: Gingival squamous cell carcinoma, bone invasion. controversial. Jaw bone invasion of oral SCC was reported to have an adverse effect on prognosis in one report (4) contrary to another (5). In other reports, bone marrow invasion of oral SCC affected prognosis, but cortical invasion did not $(1,6)$. Oral SCC also has an aggressive type, which causes bone destruction, and a type that is not so aggressive; it has been reported that a vicious cycle between cancer cells and the bone microenvironment in the former type of SCC enhances bone destruction $(7,8)$. Recently, Fives et al. reported that mandibular medullary bone invasion is an indicator of poor prognosis in oral cancer, regardless of the size of the primary tumor (2).

Oral cavity SCC invading through cortical bone is classified as T4a according to the American Joint Committee on Cancer, Cancer Staging Manual, 7th Edition (9). In the TNM supplement (4th edition) published in 2012, it was clarified that there must be invasion through the cortical bone and involving the spongiosa (medullary cavity) for a T4a classification (10). Multivariate analyses taking into account potential confounding factors such as tumor size and involved margins have suggested that bone invasion is an independent predictor of survival $(2,6)$.

The aim of this study was to define the variables that influence local recurrence and survival and determine whether bone invasion is an independent prognostic factor in gingival SCC.

\section{Patients and Methods}

Patients. The 78 patients included in the study were diagnosed and treated for upper or lower gingival SCC individually at the Okayama University Hospital (Okayama, Japan) Department of Oral and Maxillofacial Surgery (Biopathology) from January 2005 through December 2015. All patients were followed until death or the end of 2016. We investigated the relationship between the clinical and histopathological factors of these 78 cases.

Tumors were staged using the International Union against Cancer Classification (UICC) for TNM (11). The grade of tumor 
differentiation was determined according to the criteria of the WHO histological typing of oral and oropharyngeal tumors (12).

Histopathological analysis. Hematoxylin-eosin staining was performed on the resected specimens, and the boundary between the tumor and the bone was observed. As shown in Figure 1, bone invasion was categorized as no bone invasion when there was a fibrous connective tissue layer at the boundary between the tumor and bone, cortical when the bone invasion was limited to the cortex, and medullary when extension into the cancellous bone was present. The study population consisted of 78 patients with primary gingival SCC treated by surgical resection, with 38 undergoing concurrent neck dissection. The presence or absence of extracapsular nodal spread was confirmed for cases in which neck dissection was performed.

Statistical analysis. Cross-tabulated data were analyzed using the chi-square test or Fisher exact test where appropriate. The overall survival (OS) and disease-specific survival (DSS) rates were calculated by Kaplan-Meier methods, and statistical significance was analyzed by the log-rank test. Univariate Cox proportional hazards regression was used to test the association of bone invasion with OS and DSS. Other potential covariates, including age at diagnosis, gender, tumor site, tumor size, pathological $\mathrm{N}(\mathrm{pN})$ classification, differentiation, lymphovascular invasion, perineural invasion, extracapsular nodal spread and history of tooth extraction at the site of the primary tumor, were also tested for prognostic significance. Statistically significant and clinically important covariates were used to create a multivariate Cox proportional hazards regression model to determine whether bone invasion is an independent prognostic factor. Values of $p<0.05$ were considered statistically significant.

\section{Results}

Patient demographics. Table I shows the clinicopathological characteristics of patients. The 78 cases of gingival SCC included 32 patients affected in the upper gingiva (13 males and 19 females) and 46 cases in the lower gingiva (16 males, 30 females), with an average age of 72.7 years (range $=38$ 89 years), and median follow-up period of 49.8 months. Twenty-five patients underwent chemotherapy or radiotherapy or both before surgery; thirty-eight patients (upper gingiva 9 cases, lower gingiva 29 cases) had neck dissection at the same time as tumor resection.

Ten cases ( 4 cases of upper gingiva, 6 cases of lower gingiva) had a history of tooth extraction at the site of the primary tumor, with the period from tooth extraction to the initial visit to our hospital ranging from 10 days to 3 years. Among them, there were 8 cases who presented with complaints of a painful mass with unhealed surface and 2 cases diagnosed as SCC by histopathological examination after collecting tissue from tooth extraction cavities.

Analysis of bone invasion pattern by histopathological findings. Pathologically-proven bone invasion was present in 51 patients. Within this group, 29 had invasion limited to the cortex, whereas 22 had medullary involvement. By confirming bone invasion, $11(50 \%)$ of 22 cT4a cases became pT2, while
Table I. Clinicopathological characteristics of patients.

\begin{tabular}{|c|c|c|}
\hline Parameters & $\mathrm{N}=78$ & $\%$ \\
\hline \multicolumn{3}{|l|}{ Age, years } \\
\hline$\geq 70$ & 56 & 71.8 \\
\hline$<70$ & 22 & 28.2 \\
\hline \multicolumn{3}{|l|}{ Gender } \\
\hline Male & 29 & 37.2 \\
\hline Female & 49 & 62.8 \\
\hline \multicolumn{3}{|l|}{ Tumor site } \\
\hline Upper gingiva & 32 & 41.0 \\
\hline Lower gingiva & 46 & 59.0 \\
\hline \multicolumn{3}{|c|}{ Pathological $\mathrm{T}$ classification } \\
\hline $\mathrm{T} 1$ & 10 & 12.8 \\
\hline $\mathrm{T} 2$ & 43 & 55.1 \\
\hline $\mathrm{T} 3$ & 2 & 2.6 \\
\hline $\mathrm{T} 4 \mathrm{a}$ & 21 & 26.9 \\
\hline $\mathrm{T} 4 \mathrm{~b}$ & 2 & 2.6 \\
\hline \multicolumn{3}{|c|}{ Pathological $\mathrm{N}$ classification } \\
\hline N0 & 63 & 80.8 \\
\hline N1 & 8 & 10.3 \\
\hline $\mathrm{N} 2$ & 7 & 9.0 \\
\hline \multicolumn{3}{|l|}{ Differentiation } \\
\hline Well & 49 & 62.8 \\
\hline Moderate & 23 & 29.5 \\
\hline Poor & 6 & 7.7 \\
\hline \multicolumn{3}{|l|}{ Perineural invasion } \\
\hline Absent & 70 & 89.7 \\
\hline Present & 8 & 10.3 \\
\hline \multicolumn{3}{|c|}{ Lymphovascular invasion } \\
\hline Absent & 72 & 92.3 \\
\hline Present & 6 & 7.7 \\
\hline \multicolumn{3}{|l|}{ Bone invasion } \\
\hline No bone invasion & 27 & 34.6 \\
\hline Cortical & 29 & 37.2 \\
\hline Medullary & 22 & 28.2 \\
\hline \multicolumn{3}{|c|}{ Extracapsular nodal spread } \\
\hline Absent & 34 & \\
\hline Present & 4 & \\
\hline \multicolumn{3}{|c|}{$\begin{array}{l}\text { History of tooth extraction at the } \\
\text { site of the primary tumor }\end{array}$} \\
\hline Absent & 68 & 87.2 \\
\hline Present & 10 & 12.8 \\
\hline
\end{tabular}

$1(9.1 \%)$ of 11 cT 1 cases, $7(17.9 \%)$ of 39 cT2 cases and 2 $(50 \%)$ of 4 cT3 cases became pT4a. There was a significant association between bone invasion and tumor size $(p=0.017)$, $\mathrm{pN}$ classification $(p<0.001)$, differentiation $(p=0.017)$ and lymphovascular invasion $(p=0.007)$ (Table II). In particular, cases with tumor size $\geq 4 \mathrm{~cm}, \mathrm{pN} 2$, poor differentiation and lymphovascular invasion had a high percentage of medullary bone invasion. There was no association between bone invasion and tumor site.

Survival analysis. The 5-year OS of patients with medullary invasion was significantly reduced, at $52.9 \%$, whereas that 

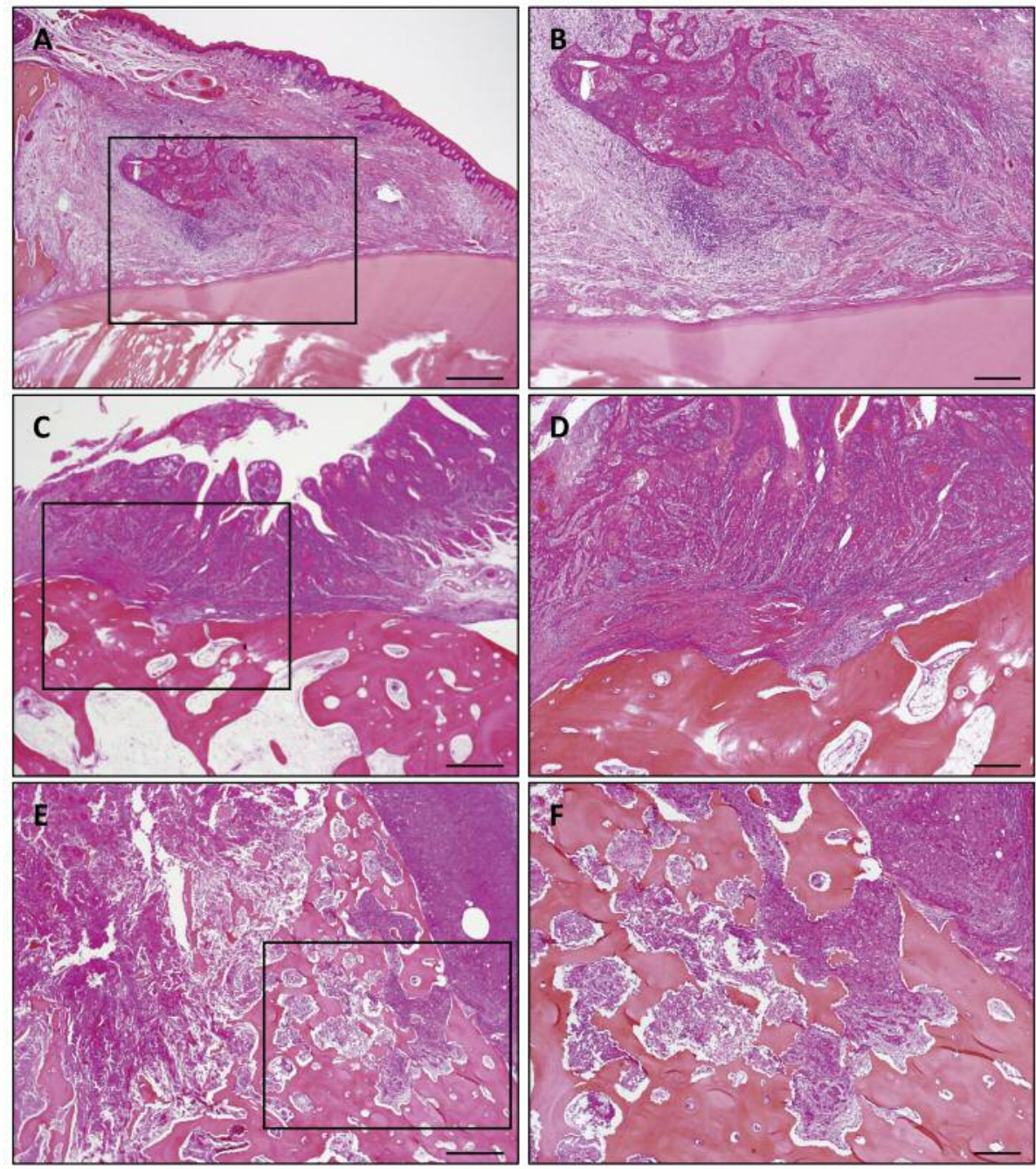

Figure 1. Representative pathology image of bone invasion. Bone invasion was categorized as (A and B) no bone invasion when there was a fibrous connective tissue layer at the boundary between the tumor and bone, $(C$ and $D)$ cortical when the bone invasion was limited to the cortex, and $(E$ and $F$ ) medullary when extension into the cancellous bone was present. Each right-hand photo is a magnification of the rectangular delimited area in the corresponding left-hand photo. Hematoxylin-Eosin staining ( $A, C$ and E: bar=500 $\mu \mathrm{m}, B, D$ and F: bar=200 $\mu \mathrm{m}$ ).

of patients with cortical bone invasion was $88.0 \%$ and that of those with no bone invasion was $96.3 \%$. Similarly, patients with medullary invasion had a significantly reduced 5 -year DSS of $57.8 \%$, whereas those of patients with cortical bone invasion and no bone invasion were $100 \%$ and $96.3 \%$, respectively. In upper and lower gingiva SCC, medullary bone invasion was associated with significantly worse OS and DSS (Figure 2).

Univariate analysis identified tumor size, $\mathrm{pN} 1$ or $\mathrm{pN} 2$, poor differentiation, lymphovascular invasion, perineural invasion, extracapsular nodal spread and medullary bone invasion as factors associated with significantly worse OS, and all of these factors except for tumor size were also associated with significantly worse DSS (Table III). Multivariate analysis was performed on survival rate with factors identified as significant by univariate analysis. Pathologically proven medullary bone invasion $(p=0.015)$ and lymphovascular invasion $(p=0.048)$ were independent predictors of reduced OS, and medullary bone invasion was also an independent predictor of reduced DSS $(p=0.018)$. There were no significant differences in OS or DSS according to tumor site (lower gingiva $v s$. upper gingiva). Since lymphovascular invasion was an independent predictor of reduced OS, we analyzed the association between lymphovascular invasion and various factors. The proportion of secondary cervical lymph metastasis cases was high 


\section{A}

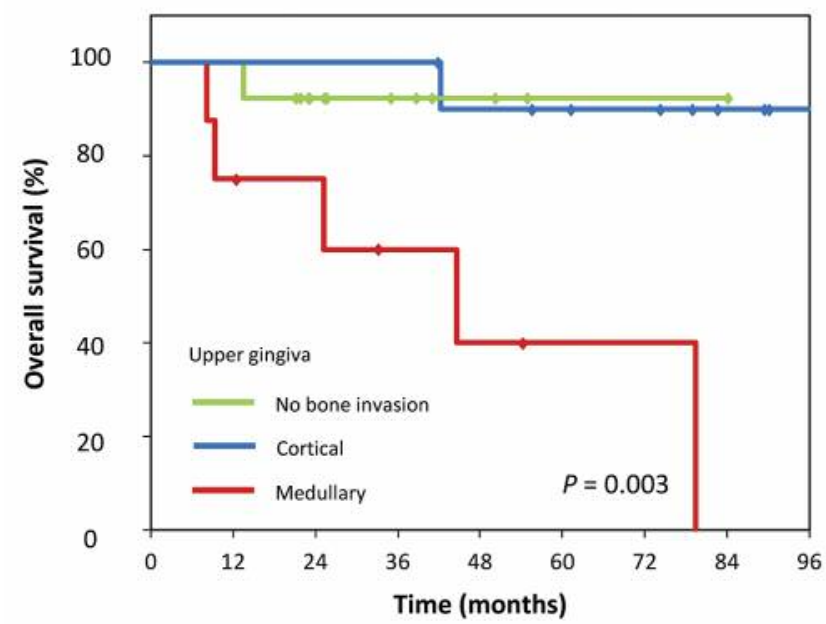

C

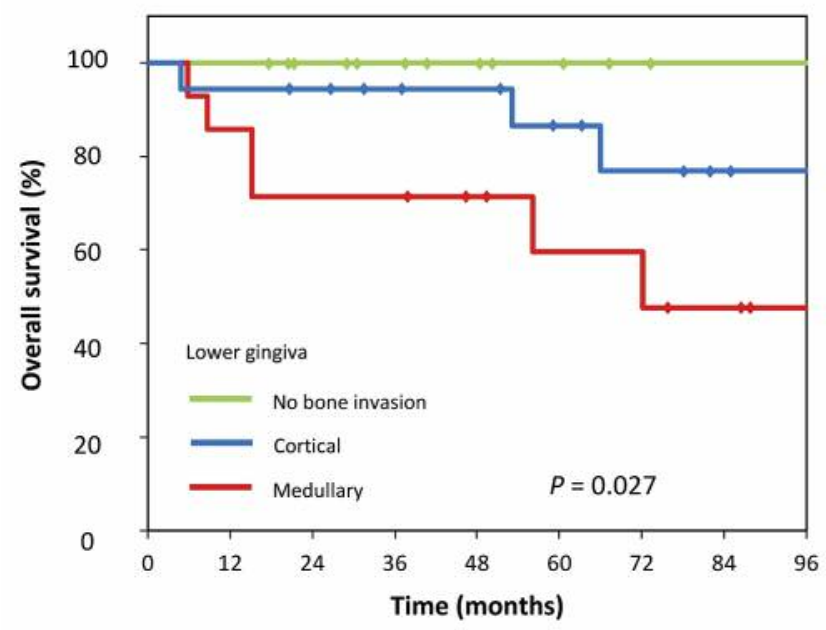

B

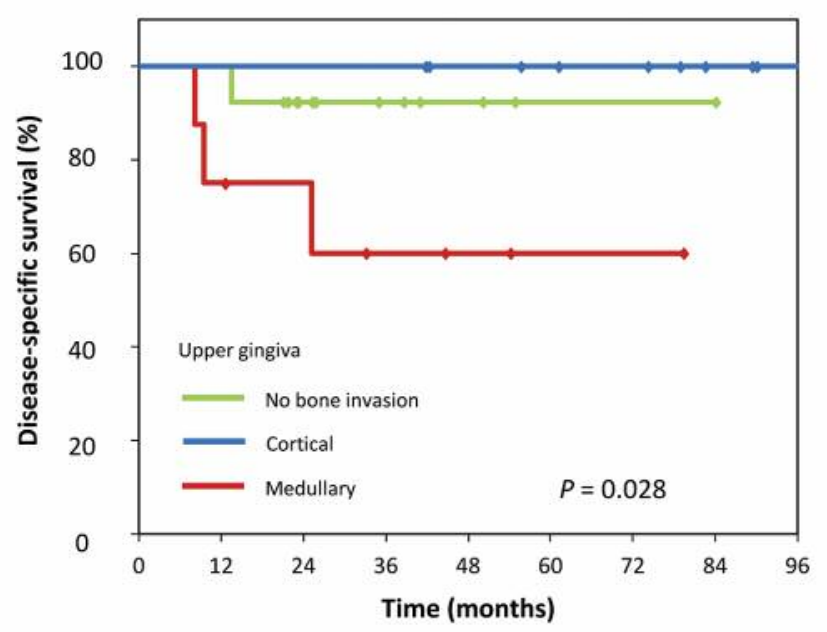

D

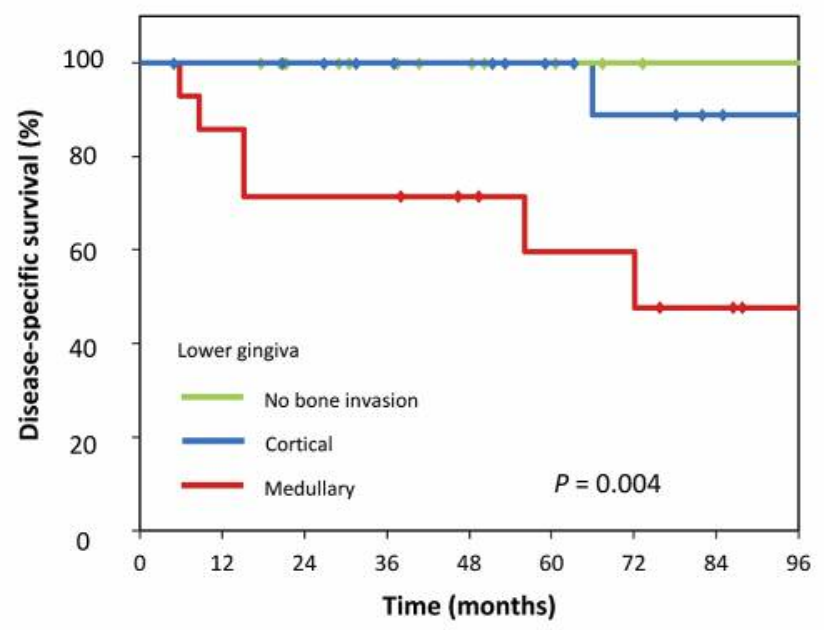

Figure 2. Kaplan-Meier curves of (A) Upper gingiva, overall survival and (B) Upper gingiva, disease-specific survival (C) Lower gingiva, overall survival and $(D)$ Lower gingiva, disease-specific survival are shown according to the presence and depth of bone invasion.

among those with lymphovascular invasion $(p=0.0043)$. There was no significant association between lymphovascular invasion and primary recurrence $(p=0.2604)$. There was no significant difference in OS or DSS for cases in which tooth extraction and curettage were performed due to an erroneous diagnosis of gingival cancer as periodontitis. There was one case in which local recurrence occurred after tooth extraction; that case was an upper-gingiva SCC patient who visited our hospital 3 years after tooth extraction, and her outcome was poor.

Thirty-eight of 78 cases ( 9 upper gingiva cases, 29 lower gingiva cases) had neck dissection at the same time as tumor resection. In $8(25 \%)$ of the 32 upper gingiva cases and 4 $(8.7 \%)$ of the 46 lower gingiva cases, secondary cervical lymph node metastasis was observed $(p=0.0496)$. Patients with upper gingiva SCC were less likely to have neck dissection, but their secondary cervical lymph node metastasis rate was higher. Primary recurrence was observed in $4(12.5 \%)$ of the 32 upper gingiva cases and $9(19.6 \%)$ of the 46 lower gingiva cases $(p=0.410)$.

\section{Discussion}

The AJCC staging system for oral SCC continues to classify tumors with invasion through the cortical bone as T4 (9), which automatically assigns the patient to stage IV disease with resultant prognostic and management implications. Ebrahimi et al. recommend a revision of the $\mathrm{T}$ staging system such that tumors are classified as $\mathrm{T} 1$ to $\mathrm{T} 3$ based on size and then upstaged by $1 \mathrm{~T}$ stage in the presence of 
Table II. Analysis of bone invasion and clinicopathological characteristics

\begin{tabular}{|c|c|c|c|c|c|}
\hline \multirow[t]{2}{*}{ Parameters } & \multicolumn{3}{|c|}{ Bone invasion } & \multirow[b]{2}{*}{ Total } & \multirow[b]{2}{*}{$p$-Value } \\
\hline & No bone invasion & Cortical & Medullary & & \\
\hline \multicolumn{6}{|l|}{ Age, year } \\
\hline$\geq 70$ & $17(30.4 \%)$ & $20(35.7 \%)$ & $19(33.9 \%)$ & 56 & \multirow[t]{2}{*}{0.177} \\
\hline$<70$ & $10(45.5 \%)$ & $9(40.9 \%)$ & $3(13.6 \%)$ & 22 & \\
\hline \multicolumn{6}{|l|}{ Gender } \\
\hline Female & $17(34.7 \%)$ & $17(34.7 \%)$ & $15(30.6 \%)$ & 49 & \multirow[t]{2}{*}{0.783} \\
\hline Male & $10(34.5 \%)$ & $12(41.4 \%)$ & $7(24.1 \%)$ & 29 & \\
\hline \multicolumn{6}{|l|}{ Tumor site } \\
\hline Upper gingiva & $13(40.6 \%)$ & $11(34.4 \%)$ & $8(25.0 \%)$ & 32 & \multirow[t]{2}{*}{0.645} \\
\hline Lower gingiva & $14(30.4 \%)$ & $18(39.1 \%)$ & $14(30.4 \%)$ & 46 & \\
\hline \multicolumn{6}{|l|}{ Tumor size } \\
\hline$<2 \mathrm{~cm}$ & $7(63.6 \%)$ & $3(27.3 \%)$ & $1(9.1 \%)$ & 11 & \multirow[t]{3}{*}{0.017} \\
\hline$\geq 2 \mathrm{~cm},<4 \mathrm{~cm}$ & $18(32.1 \%)$ & $24(42.9 \%)$ & $14(25.0 \%)$ & 56 & \\
\hline$\geq 4 \mathrm{~cm}$ & $2(18.2 \%)$ & $2(18.2 \%)$ & $7(63.6 \%)$ & 11 & \\
\hline \multicolumn{6}{|c|}{ Pathological N classification } \\
\hline NO & $27(42.9 \%)$ & $22(34.9 \%)$ & $14(22.2 \%)$ & 63 & \multirow[t]{3}{*}{$<0.001$} \\
\hline N1 & 0 & $6(75 \%)$ & $2(25 \%)$ & 8 & \\
\hline $\mathrm{N} 2$ & 0 & $1(14.3 \%)$ & $6(85.7 \%)$ & 7 & \\
\hline \multicolumn{6}{|l|}{ Differentiation } \\
\hline Well & $21(42.9 \%)$ & $18(36.7 \%)$ & $10(20.4 \%)$ & 49 & \multirow[t]{3}{*}{0.017} \\
\hline Moderate & $6(26.1 \%)$ & $10(43.5 \%)$ & $7(30.4 \%)$ & 23 & \\
\hline Poor & 0 & $1(16.7 \%)$ & $5(83.3 \%)$ & 6 & \\
\hline \multicolumn{6}{|c|}{ Lymphovascular invasion } \\
\hline Absent & $27(37.5 \%)$ & $28(38.9 \%)$ & $17(23.6 \%)$ & 72 & \multirow[t]{2}{*}{0.007} \\
\hline Present & 0 & $1(16.7 \%)$ & $5(83.3 \%)$ & 6 & \\
\hline \multicolumn{6}{|c|}{ Perineural invasion } \\
\hline Absent & $25(35.7 \%)$ & $28(40.0 \%)$ & $17(24.3 \%)$ & 70 & \multirow[t]{2}{*}{0.067} \\
\hline Present & $2(25.0 \%)$ & $1(12.5 \%)$ & $5(62.5 \%)$ & 8 & \\
\hline \multicolumn{6}{|c|}{ Extracapsular nodal spread } \\
\hline Absent & $7(20.6 \%)$ & $14(41.2 \%)$ & $13(38.2 \%)$ & 34 & \multirow[t]{2}{*}{0.063} \\
\hline Present & 0 & 0 & $4(100 \%)$ & 4 & \\
\hline \multicolumn{6}{|c|}{ History of tooth extraction at the site of the primary tumor } \\
\hline Absent & $25(36.8 \%)$ & $23(33.8 \%)$ & $20(29.4 \%)$ & 68 & \multirow[t]{2}{*}{0.274} \\
\hline Present & $2(20.0 \%)$ & $6(60.0 \%)$ & $2(20.0 \%)$ & 10 & \\
\hline \multicolumn{6}{|c|}{ Primary recurrence } \\
\hline Absent & $24(36.9 \%)$ & $25(38.5 \%)$ & $16(24.6 \%)$ & 65 & \multirow[t]{2}{*}{0.279} \\
\hline Present & $3(23.1 \%)$ & $4(30.8 \%)$ & $6(46.2 \%)$ & 13 & \\
\hline Secondary cervic & & & & & \\
\hline Absent & $25(37.9 \%)$ & $24(36.4 \%)$ & $17(25.8 \%)$ & 66 & 0.315 \\
\hline Present & $2(16.7 \%)$ & $5(41.7 \%)$ & $5(41.7 \%)$ & 12 & \\
\hline
\end{tabular}

medullary bone invasion (6). In this study, by confirming bone invasion, $11(50 \%)$ of 22 cT4 cases became pT2. Conversely, there were 10 cases ( 1 cT1 case, 7 cT2 cases and 2 cT3 cases) in which medullary bone invasion was observed histopathologically but not on imaging. Among those whose bone invasion was diagnosed as minor in the preoperative images, there were many cases with poor outcomes, because marginal resection rather than segmental mandibulectomy had been selected.

Medullary bone invasion of oral SCC has been reported to have an adverse effect on prognosis (4). Okura et al. reported that invasion extending into the mandibular canal was an independent predictor of OS. But invasion into cancellous bone (but not extending into the mandibular canal) was an independent variable for distant control (3). We defined the variables that influence local recurrence and survival and sought to determine whether bone invasion is an independent prognostic factor in gingival SCC. As expected, medullary bone invasion and lymphovascular invasion were independent predictors of reduced OS; medullary bone invasion was also an independent predictor of reduced DSS. Lymphovascular and perineural invasion 
Table III. Analysis of overall and disease-specific survival.

\begin{tabular}{|c|c|c|c|c|c|c|c|c|}
\hline \multirow[t]{2}{*}{ Parameters } & \multicolumn{4}{|c|}{ Overall survival } & \multicolumn{4}{|c|}{ Disease-specific survival } \\
\hline & $\begin{array}{c}\text { Univariate } \\
\text { analysis } \\
\text { HR } \\
(95 \% \mathrm{Cl})\end{array}$ & $p$-Value & $\begin{array}{l}\text { Multivariate } \\
\text { analysis } \\
\text { HR } \\
(95 \% \mathrm{Cl})\end{array}$ & $p$-Value & $\begin{array}{c}\text { Univariate } \\
\text { analysis } \\
\text { HR } \\
(95 \% \mathrm{Cl})\end{array}$ & $p$-Value & $\begin{array}{l}\text { Multivariate } \\
\text { analysis } \\
\text { HR } \\
(95 \% \mathrm{Cl})\end{array}$ & $p$-Value \\
\hline \multicolumn{9}{|l|}{ Age, years } \\
\hline$\geq 70 /<70$ & $\begin{array}{c}3.021 \\
(0.686-13.300)\end{array}$ & 0.144 & & & $\begin{array}{c}1.691 \\
(0.359-7.967)\end{array}$ & 0.507 & & \\
\hline \multicolumn{9}{|l|}{ Gender } \\
\hline Female/Male & $\begin{array}{c}1.150 \\
(0.398-3.321)\end{array}$ & 0.796 & & & $\begin{array}{c}1.294 \\
(0.334-5.007)\end{array}$ & 0.709 & & \\
\hline \multicolumn{9}{|l|}{ Tumor site } \\
\hline Lower/Upper & $\begin{array}{c}0.792 \\
(0.294-2.131)\end{array}$ & 0.644 & & & $\begin{array}{c}0.972 \\
(0.273-3.454)\end{array}$ & 0.965 & & \\
\hline \multicolumn{9}{|l|}{ Tumor size } \\
\hline$\geq 4 \mathrm{~cm} /<4 \mathrm{~cm}$ & $\begin{array}{c}3.145 \\
(1.090-9.073)\end{array}$ & 0.034 & $\begin{array}{c}0.849 \\
(0.144-4.990)\end{array}$ & 0.856 & $\begin{array}{c}2.924 \\
(0.754-11.334)\end{array}$ & 0.121 & & \\
\hline \multicolumn{9}{|c|}{ Pathological N classification } \\
\hline N1, N2/N0 & $\begin{array}{c}3.345 \\
(1.240-9.019)\end{array}$ & 0.017 & $\begin{array}{c}1.176 \\
(0.263-5.267)\end{array}$ & 0.832 & $\begin{array}{c}7.003 \\
(1.965-24.956)\end{array}$ & 0.003 & $\begin{array}{c}1.412 \\
(0.158-12.643)\end{array}$ & 0.758 \\
\hline \multicolumn{9}{|l|}{ Differentiation } \\
\hline Poor/Moderate, Well & $\begin{array}{c}7.100 \\
(2.255-22.352)\end{array}$ & 0.0008 & $\begin{array}{c}3.299 \\
(0.422-25.793)\end{array}$ & 0.255 & $\begin{array}{c}13.040 \\
(3.641-46.705)\end{array}$ & $<0.0001$ & $\begin{array}{c}3.927 \\
(0.876-17.602)\end{array}$ & 0.074 \\
\hline \multicolumn{9}{|c|}{ Lymphovascular invasion } \\
\hline Present/Absent & $\begin{array}{c}10.483 \\
(3.015-36.454)\end{array}$ & 0.0002 & $\begin{array}{c}5.060 \\
(1.015-25.220)\end{array}$ & 0.048 & $\begin{array}{c}19.092 \\
(4.657-78.270)\end{array}$ & $<0.0001$ & $\begin{array}{c}6.234 \\
(0.777-50.009)\end{array}$ & 0.085 \\
\hline \multicolumn{9}{|l|}{ Perineural invasion } \\
\hline Present/Absent & $\begin{array}{c}3.709 \\
(1.191-11.550)\end{array}$ & 0.024 & $\begin{array}{c}0.719 \\
(0.160-3.231)\end{array}$ & 0.667 & $\begin{array}{c}4.746 \\
(1.222-18.434)\end{array}$ & 0.025 & $\begin{array}{c}0.573 \\
(0.103-3.201)\end{array}$ & 0.526 \\
\hline \multicolumn{9}{|c|}{ Extracapsular nodal spread } \\
\hline $\begin{array}{l}\text { Present/Absent, } \\
\text { not neck dissection }\end{array}$ & $\begin{array}{c}6.720 \\
(1.887-23.931)\end{array}$ & 0.003 & $\begin{array}{c}0.977 \\
(0.170-5.632)\end{array}$ & 0.980 & $\begin{array}{c}13.129 \\
(3.316-51.987)\end{array}$ & 0.0002 & $\begin{array}{c}1.258 \\
(0.210-7.525)\end{array}$ & 0.801 \\
\hline $\begin{array}{l}\text { Bone invasion } \\
\text { Medullary/Cortical, } \\
\text { No bone invasion }\end{array}$ & $\begin{array}{c}5.242 \\
(1.653-16.620)\end{array}$ & 0.005 & $\begin{array}{c}4.598 \\
(1.338-15.800)\end{array}$ & 0.015 & $\begin{array}{c}27.289 \\
(3.453-215.663)\end{array}$ & 0.002 & $\begin{array}{c}14.484 \\
(1.564-128.593)\end{array}$ & 0.018 \\
\hline $\begin{array}{l}\text { History of tooth extract } \\
\text { at the site of the primar } \\
\text { Present/Absent }\end{array}$ & $\begin{array}{c}0.356 \\
(0.047-2.705)\end{array}$ & 0.318 & & & $\begin{array}{c}0.662 \\
(0.083-5.263)\end{array}$ & 0.697 & & \\
\hline
\end{tabular}

showed a significant association with tumor size, histological grading, nodal metastasis, status of resection margins, local recurrence and survival (13). An assessment of lymphovascular invasion is still thought to be valuable since its detection in random tissue sections statistically implies that a considerable number of tumor cells are entering the vascular compartment, thus increasing the likelihood of successful metastatic growth (14). In our study, the proportion of secondary cervical lymph node metastasis cases was high among those with lymphovascular invasion. There were no significant differences in the number of primary recurrence or secondary cervical lymph node metastasis cases between those with and without medullary bone invasion, but medullary bone invasion did have an impact on lymphovascular invasion. The treatment failures in patients with medullary bone invasion were because of distant metastases; these patients should be considered for adjuvant systemic therapy (6). The results suggest that it is important to grasp the extent of bone invasion by imaging before surgery, and that it is necessary to consider adjuvant therapy in patients with medullary bone invasion.

Bone invasion of mandibular shows two different types of invasion. In one, the periosteum is destroyed and the external surface of the cortical bone is resorbed through osteoclastic 
action; then, tumor cells fill in the area of the cortical bone resorption. In the other, tumor cells invade the bone marrow through enlarged Volkmann and Haversian canals or the periodontal space or by direct resorption of the cortical bone, thus replacing the marrow spaces $(15,16)$. The maxilla has a lower bone density than the mandible and is considered to be porous. Since the maxillary sinus and the nasal cavity exist in the upper part and the pterygoid fossa in the back, tumors in this region tend to invade the adjacent tissue (17). Our study showed no significant association between tumor site (upper vs. lower gingiva) and bone invasion. There was no difference in the ratio of bone invasion due to bone quality between the maxilla and the mandible. However, patients with upper gingiva SCC had fewer neck dissections and a higher rate of secondary cervical lymph node metastasis. There is a pathway for lymph vessels from the maxilla to the neck through the buccal lymph nodes into the submandibular lymph nodes (18). There is another pathway by which the lymph vessels of the maxilla gather in the midline of the nasal floor or soft palate and flow out into the bilateral upper jugular lymph nodes through the parapharyngeal space or node of Rouvière $(18,19)$. In maxillary SCC, the metastatic pathway to the node of Rouvière is a problem and often becomes uncontrollable. Elective neck dissection is indicated for all stages of mandibular gingival tumors and T3/T4 carcinomas of the upper gingiva, but elective neck dissection should even be considered in T2 maxillary SCC (20). In our study, there were no significant associations between tumor site (upper $v s$. lower gingiva) and survival rate, but it is still necessary to consider whether to perform preventive cervical neck dissection in upper-gingiva SCC.

Gingival squamous cell carcinomas, in particular, tend to present with benign features, and this leads to delays in diagnosis. Clinically, gingival SCC may be misdiagnosed because of its variable appearances. The similarities of gingival SCC to periodontal or periapical diseases such as pseudoepitheliomatous hyperplasia, pyogenic granuloma, aggressive periodontitis, and acute necrotizing ulcerative gingivitis, may also pose problems in diagnosis and management (21). Tooth extraction was predictive of a lower survival rate on univariate analysis (22). However, tooth extraction did not affect local control or survival of lowergingival carcinoma in the analysis of Overholt et al. (23). Choi et al. reported that more aggressive treatment, such as setting a broad surgical field and enforcing preventive neck dissection, can improve outcomes, although these invasive procedures are associated with increased rates of subsequent cancer bone invasion and neck metastasis (24). In our study, 10 out of 78 cases had a history of tooth extraction at the primary site of the tumor, but there were no significant associations between tooth extraction and bone invasion, recurrence, or survival rate.
In summary, bone invasion and lymphovascular invasion were found to be key prognostic factors in gingival SCC; hence, addressing bone invasion is likely a key to improving treatment outcomes. The results suggest that it is necessary to consider adjuvant therapy in patients with medullary bone invasion.

\section{Acknowledgements}

This work was partly supported by a Grant-in-Aid for Scientific Research (B) (\#JP26293428 to T.S.) and Grant-in-Aid for Young Scientists (B) (\#JP16K20579 to S.Y.) from Japan Society for the promotion of Sciences, Japan.

\section{References}

1 Fried D, Mullins B, Weissler M, Shores C, Zanation A, Hackman T, Shockley W, Hayes N and Chera BS: Prognostic significance of bone invasion for oral cavity squamous cell carcinoma considered T1/T2 by American joint committee on cancer size criteria. Head Neck 36: 776-781, 2014.

2 Fives C, Nae A, Roche P, O'Leary G, Fitzgerald B, Feeley L and Sheahan P: Impact of mandibular invasion on prognosis in oral squamous cell carcinoma four centimeters or less in size. Laryngoscope 127: 849-854, 2017.

3 Okura M, Yanamoto S, Umeda M, Otsuru M, Ota Y, Kurita H, Kamata T, Kirita T, Yamakawa N, Yamashita T, Ueda M, Komori T, Hasegawa T and Aikawa T; Japan Oral Oncology Group: Prognostic and staging implications of mandibular canal invasion in lower gingival squamous cell carcinoma. Cancer Med 5: 3378-3385, 2016.

4 Muñoz Guerra MF, Naval Gías L, Campo FR and Pérez JS: Marginal and segmental mandibulectomy in patients with oral cancer: a statistical analysis of 106 cases. J Oral Maxillofac Surg 61: 1289-1296, 2003.

5 Patel RS, Dirven R, Clark JR, Swinson BD, Gao K and O'Brien CJ: The prognostic impact of extent of bone invasion and extent of bone resection in oral carcinoma. Laryngoscope 118: 780-785, 2008.

6 Ebrahimi A, Murali R, Gao K, Elliott MS and Clark JR: The prognostic and staging implications of bone invasion in oral squamous cell carcinoma. Cancer 117: 4460-4467, 2011.

7 Shimo $\mathrm{T}$ and Sasaki A: Mechanism of cancer-induced bone destruction: An association of connective tissue growth factor (CTGF/CCN2) in the bone metastasis. Jap Dent Sci Rev 47: 1322,2011

8 Shimo T, Kubota S, Goda T, Yoshihama Y, Kurio N, Nishida T, $\mathrm{Ng}$ PS, Endo K, Takigawa M and Sasaki A: Clinical significance and pathogenic function of connective tissue growth factor (CTGF/CCN2) in osteolytic mandibular squamous cell carcinoma. Anticancer Res 28: 2343-2348, 2008.

9 Edge SB, Byrd DR, Compton CC, Fritz AG, Greene FL and Trotti A (eds.). AJCC Cancer Staging Manual. 7th ed. Springer, New York, 2010

10 Wittekind $\mathrm{CH}$, Compton CC, Brierley J and Sobin LH: TNM Supplement. 4th ed. Wiley-Blackwell, New York, 2012.

11 Sobin LH, Gospodarowicz MK and Wittekind C: TNM Classification of Malignant Tumours. 7th ed, Wiley-Blackwell, New York, 2009. 
12 Barnes L, Everson JW, Reichart P and Sidransky D: World Health Organization Classification of Tumours, Pathology and Genetics of Head and Neck Tumours. IARC Press, London, pp. 168-175, 2005.

13 Scully $\mathrm{C}$ and Bagan J: Oral squamous cell carcinoma overview. Oral Oncol 45: 301-308, 2009.

14 Woolgar JA: Histopathological prognosticators in oral and oropharyngeal squamous cell carcinoma. Oral Oncol 42: 229 239, 2006

15 Totsuka Y, Amemiya A and Tomita K: Histopathologic study of bone invasion by DMBA-induced carcinoma of the mouth in the hamster. Oral Surg Oral Med Oral Pathol 62: 683-692, 1986.

16 Totsuka Y, Usui Y, Tei K, Fukuda H, Shindo M, Iizuka T and Amemiya A: Mandibular involvement of squamous cell carcinoma of the lower alveolus: analysis and comparative study of histologic and radiologic features. Head \& Neck 13: 40-50, 1991.

17 Poeschl PW, Russmueller G, Seemann R, Klug C, Poeschl E, Sulzbacher I and Ewers R: Staging and grading as prognostic factors in maxillary squamous cell carcinoma. J Oral Maxillofac Surg 69: 3038-3044, 2011.

18 Umeda M, Minamikawa T, Yokoo S and Komori T: Metastasis of maxillary carcinoma to the parapharyngeal space: rationaleand technique for concomitant en bloc parapharyngeal dissection. J Oral Maxillofac Surg 60: 408-413, 2002.

19 Umeda M, Minamikawa T, Komatsubara H, Ojima Y, Shibuya Y, Yokoo S and Komori T: En bloc resection of the primary tumour and cervical lymph nodes through the parapharyngeal space in patients with squamous cell carcinoma of the maxilla: a preliminary study. Br J Oral Maxillofac Surg 43: 17-22, 2005.
20 Lubek J, El-Hakim M, Salama AR, Liu X and Ord RA: Gingival carcinoma: retrospective analysis of 72 patients and indications for elective neck dissection. Br J Oral Maxillofac Surg 49: 182185, 2011.

21 Alsharif MJ, Jiang WA, He S, Zhao Y, Shan Z and Chen X: Gingival squamous cell carcinoma in young patients: report of a case and review of the literature. Oral Surg Oral Med Oral Pathol Oral Radiol Endod 107: 696-700, 2009.

22 Soo KC, Spiro RH, King W, Harvey W and Strong EW: Squamous carcinoma of the gums. Am J Surg 156: 281-285, 1988.

23 Overholt SM, Eicher SA, Wolf P and Weber RS: Prognostic factors affecting outcome in lower gingival carcinoma. Laryngoscope 106: 1335-1339, 1996.

24 Choi EJ, Zhang X, Kim HJ, Nam W and Cha IH: Prognosis of gingival squamous cell carcinoma diagnosed after invasive procedures. Asian Pac J Cancer Prev 12: 2649-2652, 2011.
Received October 27, 2017

Revised November 23, 2017

Accepted November 24, 2017 